\title{
The Use of Communication Technology to Manage Work-Home Boundaries
}

\author{
Cheryl L. Adkins \\ Longwood University \\ Farmville, VA \\ Sonya A. Premeaux \\ University of Arkansas \\ Little Rock, AR
}

Author's Notes

Correspondence concerning the article should address to Cheryl L. Adkins, Longwood University, College of Business and Economics, Farmville, VA 23909. E-mail: adkinscl@longwood.edu

\begin{abstract}
Communication technologies have facilitated workers' ability to integrate the home and work domains; however, these tools have also allowed each domain to more frequently intrude into the other. We examined workplace policies and norms, individual preferences, and family norms and expectations as antecedents of connectivity behaviors that utilize communication technologies to bridge the boundaries between home and work. The control of interruptions from communication technology was examined as a moderator of the relationship between connectivity behavior and work-family conflict. Data were gathered from employees of two universities $(n=290)$. We found that being required to be connected after hours and role integration preference were associated with higher levels of connectivity behaviors. Connectivity behaviors were not associated with work-family conflict, nor was there support was for the proposed moderator. Job type and hours worked after hours were significantly associated with both connectivity behavior and work-family conflict.
\end{abstract}

Keywords: communication technology, work-home boundaries, workplace norms

\section{Introduction}

The introduction of the Internet, along with changes in communication technologies such as the increased use of cell phones, and personal data assistants (PDAs), have radically changed the ways that workers connect with both their jobs and their families. These devices have allowed work to be conducted outside of traditional office settings and outside of traditional work hours. This flexibility and change in connectedness has many, often contradictory, implications for workers' ability to balance work and personal life. On one hand, the fact that workers may more easily work from home and after hours may lessen work to family conflict (WFC), the extent to which the demands of the workplace are incompatible with family life (e.g. 
Greenhaus and Beutell,1985). For example, a worker may work in the evening after taking time out from the work day to attend a child's school play, work from home while waiting for home repairs, or routinely work from home in the afternoons after the end of a child's school day. Thus, the Internet and new communication technologies may greatly facilitate a worker's ability to balance work and their personal life.

Paradoxically, however, connectedness may increase WFC as work can intrude into the home domain even more. Organizations may expect workers to be constantly connected to work even in jobs which traditionally have not required workers to be "on call." In some workplaces, informal norms may create expectations that workers check e-mail in the evenings, on weekends, and even while on vacation. Other organizations may provide cell phones or PDAs and require that workers be available after hours. Thus, the use of communication technologies for crossing boundaries between work and home presents a double-edged sword with respect to WFC. The purpose of this study is to examine antecedents of the use of communication technologies to cross the boundaries between work and home consistent with Boswell and Olson-Buchanan's (2007) call to build upon their work and examine additional antecedents, and to examine the relationship between after-hours connectivity and WFC. We will begin by defining WFC, describing the boundaries between home and work, and discussing how the Internet and communication technologies may facilitate crossing, and even blurring, the boundaries. We will then present antecedents to the use of "technology-mediated devices" (Richardson \& Rothstein, 2008) to communicate with members of one domain while in another thus crossing the boundaries between work and home. Our investigation focuses on the use of technology to conduct work during "non-work" hours.

\section{The Domains of Work and Home and the Boundaries between Them}

WFC is formally defined as interrole conflict that results when an individual's participation in the work role interferes with participation in the family role (Greenhaus \& Beutell, 1985). Thus, WFC occurs when the demands of the workplace interfere with the worker's ability to respond to the demands of family life. Researchers have examined a range of factors that may lead to WFC (including work schedule, family responsibilities, and job characteristics) and a range of outcomes of WFC (including job satisfaction, organizational commitment, and turnover; see Eby, Casper, Lockwood, Bordeaux, \& Brinley, 2005 for a review).

Recently, researchers have examined the ways workers establish and maintain boundaries between work and home. Boundary theory (Ashforth, Kreiner, \& Fugate, 2000) describes individuals as creating boundaries between work and home that are defined by both time and location. Examples of temporal boundaries are the traditional nine-to-five work day, or the hours set apart to work at home in the evening. Boundaries of location are exemplified by an individual physically going to an office away from the home, or by retreating to a home office. The boundaries between home and work may create an environment that is segmented, with the work environment distinct from the home environment in terms of time and location, or integrated with an employee working from home and interspersing family concerns with work. Kreiner (2006) found that fit between the employee's preferences for segmentation and the degree of segmentation provided by the company, for example a job that allows the employee to leave work issues behind when he/she goes home, was associated with lower levels of WFC. Further, he found that WFC was lower even as the degree of segmentation provided by the 
company exceeded that desired by the employee. Kreiner, Hollensbe, and Sheep (2009) studied the tactics that members of the clergy used to manage the boundaries between home and work and found different preferences for integration versus segmentation and distinctive tactics for managing boundaries. Kossek, Lautsch, and Eaton (2006) found that employees' level of wellbeing increased with greater levels of control over where and how work was performed and higher degrees of segmentation. Kossek, Ruderman, Braddy, and Hannum (2012) found that individuals varied greatly on their approach to managing the work-home boundary. They found that cross-role interruption behaviors, perceived control of boundaries, and identity centrality of work and family roles were the three primary characteristics associated with boundary management.

The degree of segmentation versus integration is determined by the demands and policies of the workplace, and by individual preferences (Ashforth, et al., 2000). For example, an employee who works predetermined hours in a workplace away from home has a high degree of segmentation between the home and the work roles. At the other end of the spectrum, the employee who works from home and who is able to interrupt the flow of work to respond to a child's needs has a high degree of integration between the roles. Thus, depending on workplace demands and policies as well as individual preferences, the degree of a worker's work-life integration may fall anywhere along the integration-segmentation continuum. The Internet and other technology mediated devices may facilitate the transitions between boundaries or even blur the boundaries between work and home. In situations of high segmentation a worker may use a cell phone to call home on the way from work to ease the transition between home and work. In situations of higher integration, a worker may use e-mail to remain in contact with the workplace while staying at home with a sick child. However, in integrated roles, the use of the Internet and other communication technology may lead to blurring of the boundaries and ultimately to employee stress (e.g. Desrochers \& Sargent, 2004)

Similar to boundary theory, Clark (2000) developed work-family border theory to "explain how individuals manage and negotiate the work and family spheres and the borders between them in order to attain balance" (Clark, 2000, p. 750). Clark described borders as the "lines of demarcation between domains" and noted that they can be physical, temporal, or psychological. She noted that borders may vary in permeability, flexibility, blending, and strength. Permeability is described as "the degree to which elements from other domains may enter" (Clark, 2000, p. 756), and flexibility as "the extent to which a border may contract or expand, depending on the demands of one domain or the other" (Clark, 2000, p. 757). Borderkeepers, influential domain members (for example, supervisors and spouses), impact border flexibility as they apply their own ideas of what constitutes work and family, and as they protect domains and borders. Border-keepers' awareness of the demands of the other domain and their commitment to the border-crosser impact work-family balance, as do domain differences and communication patterns. However, they may also increase the flexibility and permeability of the borders beyond the desire of the worker, for example when workplace rules or norms dictate that he/she check e-mail in the evening, or be available by cell phone during vacations.

\section{A Model of Connectivity Behavior to Cross Boundaries}

Scholars addressing boundary theory indicate that the degree of segmentation versus integration a worker faces stems from workplace policies and norms, his/her own role integration preferences, and the expectations and preferences of other family members (Ashforth et al., 
2000). Border theory similarly proposes that the extent to which an individual is a central participant in a domain will determine the influence he/she has over the borders of the domain. Border theory further suggests that the degree of domain members' awareness of the worker's other domains and commitment to the worker will influence WFC (Clark, 2000). Thus, both border and boundary theory suggest that there are distinct borders and boundaries between work and home, and that the formal policies and norms of the organization, individual role integration preferences, and family norms and expectations all influence the ease with which an individual may move between the domains and, ultimately, that individual's level of WFC. The use of communication technologies may ease the individual's movement between domains, but when used to a high degree may blur the boundaries between home and work, especially if the individual prefers a low level of integration between the domains. We thus propose that workplace policies and norms, individual preferences regarding segmentation versus integration, and family norms and expectations are all antecedents of the use of Work Connectivity Behavior After-hours (WCBA; Richardson \& Benbunan-Fich, 2011) to cross or even blur the borders between the domains of work and life. Connectivity behavior may be defined as using technology such as cell phones, smart-phones, and e-mail to remain connected to the workplace outside of regular working hours. Each of the antecedents is discussed below.

\section{Antecedents of Work Connectivity Behavior After-Hours}

\section{Workplace Policies and Norms}

Workplace policies and subjective norms about communication technology use play a role in workers' WCBA. Employers may have formal policies requiring that employees be oncall during certain periods. Beyond formal policies are subjective norms. Simply having communication devices supplied by the employer may both add formal work rules and extend a subjective norm. When companies provide workers with communication devices they create the expectation that employees will be continuously available. In a study of "work-extending technology" one participant observed, "I believe that while technology has increased the ability to work from the home and outside regular business hours, it has also increased the expectation that you do so." (Towers, Duxbury, Higgins, \& Thomas, 2006, p. 615). Empirical research supports this argument. Richardson and Benbunan-Fich (2011) explored the impact of organizational distribution of wireless email devices and laptops on WCBA. Results showed that when the communication device was provided or paid for by the employer, employees used the device more often and for longer periods of time than they would have otherwise.

The study also explored the effects of subjective norms on CB. A subjective norm is "a person's perception that most people who are important to him think he should or should not perform the behavior in question" (Fishbein \& Ajzen, 1975, p. 302). In regard to WCBA, subjective norms guide workers in their beliefs about whether they should be accessible to colleagues after work hours. Subjective norms may impact WCBA independent of whether the technology was provided by the employer or the personal property of the employee. Richardson and Benbunan-Fich (2011) found that subjective norms about connectivity did positively impact both frequency and duration of WCBA. When workers believed they were expected to respond to colleagues during non-work hours, they were more likely to do so. Further, workers have been shown to match their communication technology use to that of their supervisors and to their perceptions of organizational norms (Turner, Grube, Tinsley, Lee, \& O'Pell, 2006). Moreover, 
supervisors' ratings of workers' performance seem to be positively influenced by workers' technology use (Turner, et al., 2006). We thus propose that:

H1a Workplace norms that encourage communication between work and home will be associated with higher levels of connectivity behavior.

H1b A requirement to be connected after hours will be associated with higher levels of connectivity behavior.

H1c Communication devices provided by the organization will be associated with higher levels of connectivity behavior.

\section{Individual Role Integration Preferences}

As noted, workers differ in their preferences for segmentation versus integration of the domains of work and life (Ashforth et al., 2000). One way individual preferences are manifest is in the workers' use of communication technologies to remain connected to the workplace and in their actual patterns of connection. For example, Golden and Geisler (2007) investigated how workers used PDAs to manage the boundary between work and home. Participants used their PDAs in very distinct patterns ranging from segregating to fully integrating work and personal life. Their results indicate that individuals have diverse and sometimes contradictory goals for boundary management and these goals can vary even within individuals.

Research has shown that an individual's tendency toward multitasking, and personal innovativeness with information technology are positively correlated with WCBA (Richardson \& Benbunan-Fich, 2011). Further, workers with high ambition and job involvement (Boswell \& Olson-Buchanan, 2007), as well as those with strong role identity (Olson-Buchanan \& Boswell, 2006), are more likely to use communication technologies that allow role integration. This line of research suggests that individual preferences for role integration are likely to lead to greater WCBA use as individuals enact behaviors that accommodate their desire for fluid work-home boundaries. Thus, we propose that:

H2 Individual preferences for role integration will be positively associated with higher levels of connectivity behavior.

\section{Family Norms and Expectations}

Perceptions about subjective norms can be extended to family members who are home border-keepers, making their expectations important considerations in workers' boundary spanning behaviors. While the use of communication technologies may lead to positive outcomes due to greater flexibility in work-life borders, if family members react negatively to these blurred boundaries, undesirable outcomes are likely. According to Clark (2000), borderkeepers use their own experiences to define the work and family domains, leading some to carefully guard work-family borders which may result in decreased border flexibility thus impeding workers' ability to manage borders.

In Towers and colleagues' (2006) study on "work extending technology" the majority of respondents perceived that their families understand their need to use these technologies to work during family time; however, a substantial number also stated that their families did not like it. The mixed reactions are to be expected given the mixed results of technology's impact on 
participants' home lives. On a positive note, respondents identified benefits including their ability to work overtime at home rather than at work, to work from home while meeting family responsibilities, and improved work-family balance. On the down side, they reported that time was given to work instead of family and the devices were seen as intrusive. Similarly, Batt and Valcour (2003) found that technology facilitates workers' ability to juggle work and family, but at the same time it increases disruptions in the family domain.

It appears then that when it comes to workers' home lives, communication technology devices both allow workers more time to attend to family issues and allow work to more frequently encroach on family time. As workers struggle with balancing the use of communication devices for work with being present while at home, employees and borderkeepers alike have tried to regulate when and where connectivity is acceptable. Some families maintain strict boundaries between work and home, with workers turning their communication devices off when they don't want to be interrupted, leaving them behind, or simply not answering them (Wajcman, Bittman \& Brown, 2008). These results indicate that just as subjective norms guide employees' beliefs about the need to be accessible to colleagues (Richardson \& Benbunan-Fich, 2011), they may also guide their beliefs about not being accessible at certain times and/or in certain places. The theory of reasoned action (Fishbein \& Ajzen, 1975) suggests that if an individual perceives that his/her family expects him/her to curtail WCBA involving work while in the family domain, the individual is more likely to do so. We propose that:

H3 Family norms favoring a low degree of integration between work and home will be negatively associated with connectivity behaviors from work to home.

\section{Relationship between Connectivity Behaviors and Work-Family Conflict}

Although we argued that communication technologies can reduce and/or exacerbate WFC, the empirical investigation of the relationship between communication technology use and WFC to date suggests that WCBA is more likely to increase WFC (Batt \& Valcour, 2003; Boswell \& Olson-Buchanan, 2007; Chelsey, 2005; Olson-Buchanan \& Boswell, 2006). Communication technologies create flexibility and efficiency by allowing workers to complete work at home, but at the same time increase disruptions in the family domain (Batt \& Valcour, 2003). When engaged in WCBA, individuals are physically or psychologically unavailable to participate in non-work activities (Fenner \& Renn, 2004). As WCBAs increase access to employees when they are away from work, stress and resentment are to be expected. Thus,

H4 Using connectivity behaviors to conduct work during non-work times will be associated with higher levels of WFC.

\section{Potential Moderator}

One consideration in whether the Internet and other communication technologies exacerbate or ameliorate WFC is the controllability of interruptions. Control is one's perception of the degree of influence one has over some facet of one's environment. For example, the use of e-mail and other online features to remain connected to the workplace may be less intrusive than the use of cell phones and pagers. While the employee may easily check the former at a time of 
his/her choosing, leading to greater feelings of control, the latter are thought to demand more immediate attention and may lead workers to feel less in control. Thus, we propose that the effects of WCBA on WFC are moderated by the control of interruptions from communication technology devices.

Scholars have studied control in prior WFC research finding positive effects. Higher job control has been linked to lower WFC (Grönlund, 2007; Heponiemi, Elovainio, Pekkarinen, Sinervo, \& Kouvonen, 2008; Kossek, et al., 2006) and control over work hours has been shown to moderate the relationship between long work hours and work interference with family (Hughes \& Parkes, 2007). We expect control over interruptions from communication technologies to play a similar role here. That is, when employees exert control over their WCBA by limiting interruptions, some of the conflicts between home and work related to WCBA can be assuaged.

Workers often attempt to control what passes through work/life boundaries, allowing more or less spillover via WCBA, depending on their personal preferences. Mobile phone users have been shown to exert control over the boundary between work and home by turning off, leaving behind, or not answering the cell phone when they do not want to be interrupted (Wajcman et al., 2008). Additionally, workers may choose not to give out their phone numbers, stick to using the phone only during certain times, or not using them at all outside of normal work hours (Towers et al., 2006). Golden and Geisler (2007) have, in essence, postulated that the spirit of the PDA is control. In an investigation of how mobile technology is used to increase boundary permeability, respondents who reported not using these technologies on nights and weekends indicated that they deliberately chose not to do so in order to maintain boundaries for health and family reasons (Towers et al., 2006). We expect individuals' control of interruptions from communication technologies to moderate the relationship between WCBA and WFC. When an individual exerts control over interruptions from communication technologies, he/she is less likely to experience negative effects and more likely to experience positive effects from WCBA on WFC. Conversely, inability or unwillingness to control these interruptions will exacerbate negative outcomes of WCBA on WFC and will ameliorate positive effects. We propose that:

H5 The extent to which employees control interruptions from work to home will moderate the relationship between connectivity behaviors and work-family conflict such that greater control will weaken the relationship between connectivity behaviors and work-family conflict.

\section{Methods}

\section{Procedure and Sample}

Faculty and staff of two public universities, both in the south, were solicited to participate in an on-line survey via the universities' email systems. An email was sent to all employees of the universities explaining the purpose of the survey, providing a URL link to the web-based questionnaire, and assuring confidentiality of responses. Individuals who completed the survey were invited to enter into a drawing for a small cash prize. Names and email addresses of respondents who chose to enter the drawing were collected separately from the survey responses to maintain anonymity. We received 120 responses from one university and 170 from the second for a total sample size of 290. Response rates for the two universities were 14.87 percent and 
20.14 percent respectively. To test for differences in responses to the study variables by university we used t-tests to compare the means for each study variable. There were no significant differences; thus we combined the data from both sites for analysis.

Of those responding, 23.4\% were managers (including upper-level administrators, deans, directors, department chairs, and supervisors), $44.8 \%$ were non-managers (including classified staff and unclassified professional staff), and $31.7 \%$ were faculty. The sample was $68.73 \%$ female. Of those responding, 3.44\% were age 64 or older, $53.61 \%$ were ages $45-63,30.93 \%$ were ages $31-44$, and $12.03 \%$ were age 30 or younger.

\section{Measures}

Workplace norms and policies. We measured workplace norms using an adaptation of Venkatesh and Davis's (2000) scales for assessing subjective norms and image associated with technology acceptance (Richardson \& Benbunan-Fich, 2011). A sample items is "People at work who are important to me think that I should use communication technologies to work after hours." The five items were rated on a seven-point scale with $1=$ strongly disagree and $7=$ strongly agree $(\alpha=.85)$.

Workplace policies were measured by asking whether the employer provided the respondent with or paid for a smart phone, cell, phone, or pager $(0=$ no, $1=y e s)$, and whether the employer required the respondent to be connected to the workplace after hours or by phone or pager $(0=$ no, $1=$ yes).

Role integration preference. Role integration preference was measured with six items developed by Clark (2002). Because we were interested in the individual's preference (as opposed to the actual extent of role integration), we changed the stem of the item to "my ability to" instead of "I receive", "I have", etc. in the original items. Respondents were asked, "How much of the characteristic do you personally feel is preferable, or just enough to give you what you want? Some people prefer more or less of some family characteristics than others-we want to know how much you personally feel is preferable." A sample item is, "My ability to receive work-related calls while I am at home." The six items $(\alpha=.91)$ were rated on a seven-point scale with $1=$ not at all and $7=$ very much. The items were originally developed to measure boundary permeability and a desire for greater permeability. Individuals with a stronger preference for role integration would arguably indicate a greater desire for permeability as permeability allows workers to accommodate their desired level of integration.

Family norms and expectations. Like workplace policies and norms, the scale used to measure family norms and expectations was adapted from Venkatesh and Davis's (2000) scale for subjective norms associated with technology acceptance. The three items were revised to reflect respondents' perceptions of their families' thoughts about using communication technology to work after hours or on weekends. An example is, "Family members think that I should limit when I use communication technologies to work after hours." Our items were written to mirror Venkatesh and Davis' three items measuring subjective norms. The items measuring image were less appropriate for the family domain. Responses were rated on a seven-point scale with $1=$ strongly disagree and $7=$ strongly agree $(\alpha=.89)$. 
Connectivity behaviors. We used Richardson and Benbunan-Fich's (2011), measure of duration of WCBA by asking respondents how much time they spend using four communication technology devices (smart phone, mobile phone, laptop computer, desktop computer) to work during non-work time (e.g., before work, after work, during days off). Response categories allowed respondents to indicate their responses in ranges of minutes (none, 1-30 minutes, 31-60 minutes, 61-90 minutes, 91-120 minutes, > 2 hours). Responses for the individual technologies were summed to create an index of WCBA by device. These were then combined to create an overall index of WCBA.

Control of interruptions. Eight items measured respondents' attempts to control their use of technology for work purposes. All items were developed from interview questions used by Towers, et al., (2006) to assess how individuals tried to exert some control over how and when they used work extending technology when not at work. Respondents indicated the extent to which they use certain tactics such as turning technology off, or not accessing work e-mail while at home on a five-point scale with $1=$ never and $5=$ always $(\alpha=.79)$.

Work-family conflict. Work-family conflict was measured with five items developed by Netemeyer, Boles, and McMurrian, (1996) A sample item is, "Things I want to do at home do not get done because of the demands my job puts on me." The five items $(\alpha=.96)$ were rated on a seven-point scale with $1=$ strongly disagree and $7=$ strongly agree.

Other study variables. Respondents were asked to indicate their job type and employer. Job type was dummy coded into the two variables manager and faculty. Manager was coded $1=$ manager (including upper-level administrators, deans, directors, department chairs, and supervisors), $0=$ non-manager (including classified staff and unclassified professional staff and faculty) and faculty was coded $1=$ faculty, $0=$ non-faculty (managers and non-managers excluding faculty, as above). Respondents were also asked to indicate the number of hours worked per week outside of designated working hours.

\section{Results}

Means, standard deviations, and correlations among the study variables are shown in Table 1. As Table 1 shows, work norms, required connectivity after hours, and level of role integration desired were significantly correlated with WCBA. Work norms, family norms, and WCBA were significantly correlated with work-family conflict. Thus, the correlational data lend preliminary support to our hypotheses. 
MANAGING WORK-HOME BOUNDARIES

Table 1 Means, standard deviations, and correlations among study variables

\begin{tabular}{|c|c|c|c|c|c|c|c|c|c|c|c|c|}
\hline & Mean & $\begin{array}{l}\text { Standard } \\
\text { Deviation }\end{array}$ & 1 & 2 & 3 & 4 & 5 & 6 & 7 & 8 & 9 & 10 \\
\hline 1. Work Norms & 17.26 & 7.61 & -- & & & & & & & & & \\
\hline 2. Employer provided communication technology & .07 & .26 & $.129^{*}$ & -- & & & & & & & & \\
\hline 3. Requirement for after hours connection & .23 & .42 & $.223^{*} *$ & $.352^{* *}$ & -- & & & & & & & \\
\hline 4. Role integration desired & 27.80 & 8.90 & $.152^{* * *}$ & .108 & .001 & -- & & & & & & \\
\hline 5. Family Norms & 10.96 & 5.14 & $.228 * *$ & .010 & .065 & $-.255^{* k *}$ & -- & & & & & \\
\hline 6. Work connectivity behaviors after-hours & 8.74 & 6.65 & $.243 * *$ & .093 & $.194^{* * *}$ & $.283 * *$ & -.069 & --- & & & & \\
\hline 7. Work-family conflict & 16.98 & 9.37 & $.439 * *$ & .029 & .085 & .018 & $.228^{* *}$ & $.278^{* * *}$ & -- & & & \\
\hline 8. Control of interruptions & 21.78 & 6.24 & .013 & -.095 & -.102 & $-.350^{* 2 * k}$ & $.271^{* 0 k}$ & $-.128 *$ & .005 & -- & & \\
\hline 9. Job type: Manager & .23 & .42 & $.190^{* * *}$ & $.254 * *$ & $.199^{* 2 * k}$ & .013 & .108 & .080 & .112 & -.095 & -- & \\
\hline 10. Job type: Faculty & .32 & .47 & .108 & $-.162^{2 * *}$ & $-.198 * *$ & .080 & -.092 & $.177^{* * *}$ & $.271^{* *}$ & .051 & $-.377^{* * *}$ & -- \\
\hline 11. Hours per week worked after-hours & 8.38 & 8.83 & $.284^{* * *}$ & .027 & .061 & $.178 * *$ & $-.118^{*}$ & $.517 * *$ & $.388 * *$ & -.078 & .011 & $.445^{* *}$ \\
\hline
\end{tabular}

$* p<.05 ; * *_{p}<.01$ 
We examined the study hypotheses further using hierarchical regression analysis. We used job type and hours worked after hours as control variables. As DiRenzo, Greenhaus, and Weer (2011) indicated, work- and home-based resources and demands may be differentiallyrelated to WFC for those in higher-level jobs versus lower-level jobs. Those with managerial responsibilities are also more likely to need to be connected to the organization outside of work time. Further, faculty members frequently work at home outside of regular working hours. Faculty members generally have a higher degree of autonomy regarding the timing and location of their work outside of scheduled class times and meetings, and thus may have their own definition of "regular working hours." Following Boswell and Olson-Buchanan (2007) we controlled for hours worked after hours. It is important to examine WCBA and hours worked in conjunction with one another.

To test hypotheses 1 through 4, WCBA was regressed on job type (dummy codes for manager and faculty) and hours worked after hours in the first step. Work norms, a requirement to be connected to the workplace after hours, an employer-provided device, level of role integration desired, and family norms, were added in the second step. The results of the regression analysis are shown in Table 2.

Table 2 Regression predicting work connectivity behavior after-hours

Step 1

Job type: Manager

Job type: Faculty

Hours per week worked after hours

Step 2

Work norms

Requirement for after hours connection Employer-provided communication technology

Role integration desired

Family norms

\section{$\mathrm{WCBA}^{\mathrm{a}}$}

$.136^{*}$
$-.016^{*}$
$.295^{* *}$

Equation $F$

Equation $R^{2}$

$22.13^{* * *}$

0.19
.090

$.177^{* * * *}$

.065

$.278^{* * *}$

.030

\begin{tabular}{llc} 
& Equation $F$ & $16.75^{* * *}$ \\
& Equation $R^{2}$ & 0.32 \\
& $\Delta R^{2}$ & 0.135 \\
& $F$ for $\Delta R^{2}$ & $11.15^{* * *}$ \\
\hline${ }^{a}$ Standardized betas & & \\
${ }^{*} \mathrm{p}<.05 ;{ }^{* * *} \mathrm{p}<.01$ & &
\end{tabular}

Hypotheses 1a through 1c examined the influence of workplace policies and norms on WCBA. Hypothesis 1a, predicted that workplace norms that encourage communication between work and home would be associated with higher levels of WCBA. As Table 2 shows, this hypothesis was not supported. Hypothesis $1 \mathrm{~b}$ predicted that the requirement to be connected after 
regular hours would be associated with greater WCBA. As Table 2 indicates, the requirement to be connected after regular hours was positively associated with WCBA, even after controlling for job type and hours worked after hours, thus supporting hypothesis $1 \mathrm{~b}$. Hypothesis $1 \mathrm{c}$, which predicted that providing communication devices would lead to higher levels of WCBA, was not supported. Hypothesis 2 predicted that individual preferences for role integration would be positively associated with higher levels of WCBA. As Table 2 indicates, hypothesis 2 was supported. . Hypothesis 3 predicted that family preferences and norms favoring a low level of integration between work and home would be negatively associated with WCBA. This prediction was not supported.

The relationship between the level of WCBA and WFC was also examined using hierarchical regression analysis. WFC was regressed on the control variables job type and hours worked after hours in the first step, and WCBA was entered in the second. Hypothesis 4 predicted that WCBA would be positively associated with WFC. As Table 3 shows, the relationship between WCBA and WFC above and beyond the control variables was not statistically significant. Thus hypothesis 4 was not supported.

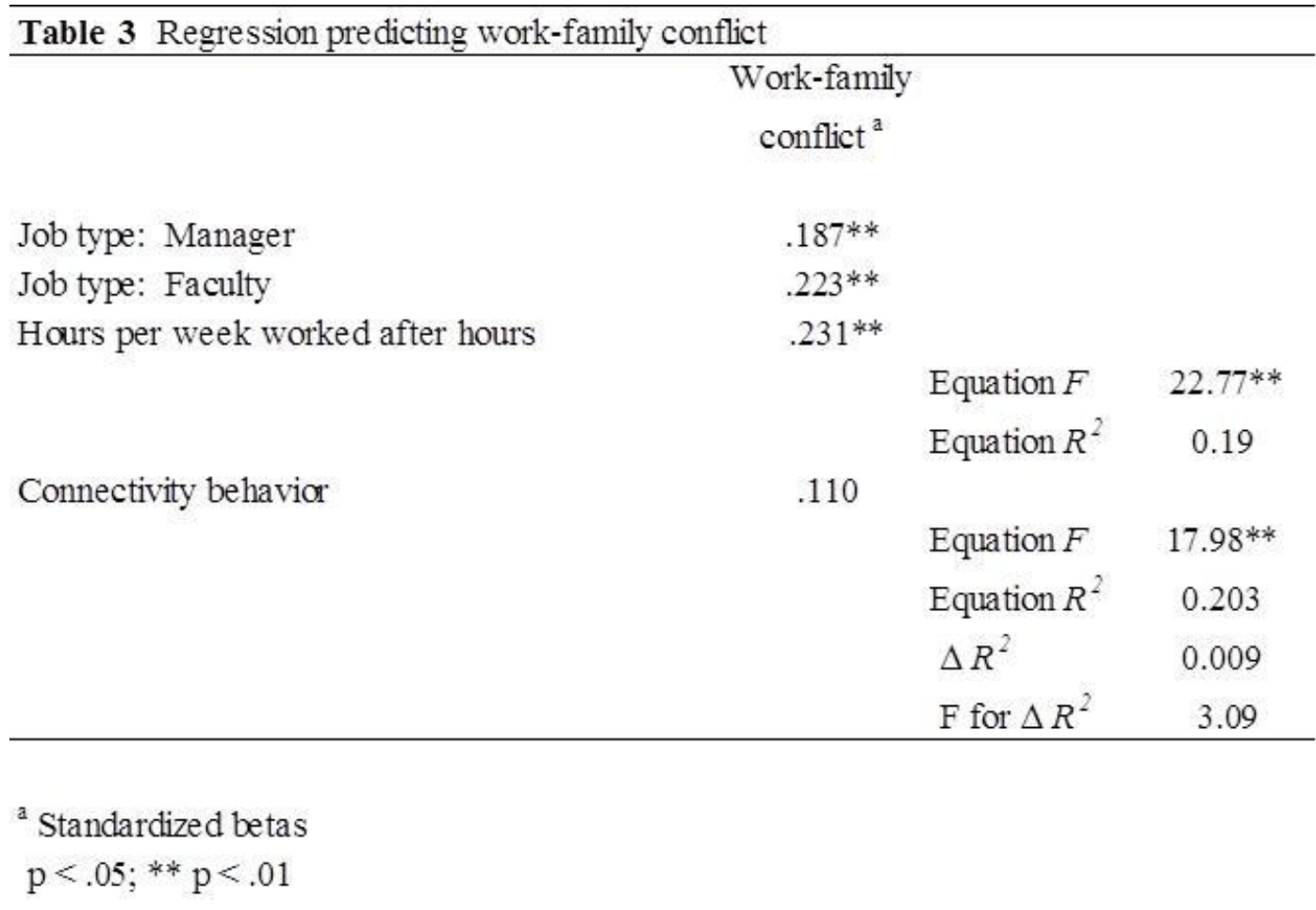

Hypothesis 5 predicted that control of interruptions would moderate the relationship between WCBA and WFC. We also examined the proposed moderator of the relationship between WCBA and WFC using hierarchical regression analysis. WFC was regressed on the control variables in the first step. Control of interruptions and WCBA were added in the second step, and the interaction term was added in the third step. As Table 4 shows, the interaction term was not significant, thus, hypothesis 5 was not supported. 
Table 4 Moderated egression predicting work-family conflict

$$
\begin{gathered}
\text { Work-family } \\
\text { conflict }^{\mathrm{a}}
\end{gathered}
$$

Job type: Manager
Job type: Faculty
Hours per week worked after hours

WCBA

Control of interruptions

WCBA * Control of interruptions

$$
\begin{aligned}
& .190^{* *} \\
& .219^{* *} \\
& .236^{* *}
\end{aligned}
$$

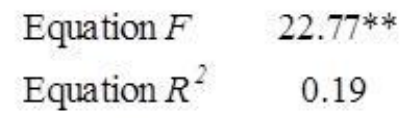

\footnotetext{
${ }^{a}$ Standardized betas

$\mathrm{p}<.05 ; * * \mathrm{p}<.01$
}

\section{Discussion}

In this study, we examined antecedents of the use of WCBA to remain connected to the workplace consistent with Boswell and Olson-Buchanan's (2007) call to examine additional antecedents of WCBA. The study built upon boundary theory (Ashforth, et al., 2000) and border theory (Clark, 2000). We further examined the relationship between WCBA and WFC. The finding that a requirement to be connected after hours (a workplace policy) was significantly associated with WCBA is consistent with Richardson and Benbunan-Fich, (2011). Consistent with the predictions of Ashforth et al., (2000) role integration preference was associated with level of WCBA. This suggests that employees who preferred a high level of integration, and thus more permeable boundaries, may have used WCBA to blur the boundaries between work and home. The finding that work norms were not significantly associated with WCBA when job type and hours worked after hours were controlled diverges from that of Boswell and OlsonBuchanan (2007). It should be noted, however, that although they also studied university employees, their sample did not include faculty. The fact that employer-provided communication devices were not significantly correlated with WCBA is very likely due to the low variance in employer-provided devices. Seven percent of the sample had communication devices supplied by the employer; however, many respondents were engaging in WCBA using personally-owned devices. 
While family norms were not associated with WCBA, they were significantly correlated with acting to control the interruptions from work to home. This suggests that while family norms may not have affected the frequency or duration of WCBA, they may have affected the times of day when workers connected to the workplace. This finding is consistent with border theory (Clark, 2000) which proposes that border keepers play a role in determining the permeability of the borders between home and work. Controlling when and how WCBA is used to cross borders or boundaries between domains is also consistent with recent research investigating the tactics individuals use to manage boundaries between home and work. According to Kreiner, et al., (2009), individuals limit boundary violations through a variety of work tactics including leveraging technology. Kelly and Moen (2007) also propose that schedule control will be associated with lower levels of WFC.

The finding that WCBA was not a significant predictor of WFC when job type and hours worked after hours were controlled diverges from that of Boswell and Olson-Buchanan (2007) as well as from Golden's (2011) finding that performing telecommuting work during nontraditional hours was associated with higher levels of WFC. This result highlights the importance of controlling for job type and hours worked. It is also consistent with Adkins and Premeaux's (2012) finding that the number of hours worked, regardless of location, was associated with WFC. Future studies should examine whether the use of technology to remain connected to the workplace increases hours worked, or simply gives employees flexibility in the location of work.

Diverging from the literature on control (e.g. Hughes \& Parkes, 2007; Kossek, et al., 2006), the control of interruptions did not moderate the relationship between WCBA and WFC. As noted previously, family norms were significantly associated with control of interruptions; therefore, such norms may have resulted in behaviors that lessened WFC. It should further be noted that control of interruptions is significantly correlated with role integration preference. Thus, individuals may have acted on their preference by actively managing the interruptions from work.

Our findings also highlight the importance of considering hours worked after hours and job type when examining the relationship between WCBA and WFC. WCBA was highly correlated with hours worked after hours $(r=.52, p<.01)$. This correlation raises an important question for future research, specifically whether the ability to remain connected to the workplace after hours increases the number of hours that individuals work. Clearly, this causal relationship should be examined in future research. WCBA was also significantly associated with faculty jobs $(r=.44, p<.01)$. Faculty reported the highest levels of WCBA, followed by managers and non-managers (means $=10.5,9.7$ and 7.0, respectively). Faculty also reported the highest level of WFC followed by managers and non-managers (means $=20.7,18.9$, and 13.4, respectively). Additionally, faculty reported the highest number of hours worked after regular hours, followed by managers and non-managers (means $=14.1,8.6$, and 4.2, respectively). Thus, the very nature of some jobs demands higher levels of WCBA after regular work hours. The jobs represented in this study also have varying degree of schedule control. Kelly and Moen (2007) define schedule control as ".... the ability to determine when one works, where one works, and perhaps how many hours one works...... (p. 491)." Faculty jobs are often characterized by a relatively high degree of schedule control, while staff positions are often less flexible. Examining WCBA in such a sample has implications extending beyond the academic setting given the trend toward more flex-time, flex-place jobs. Clearly, the relationships among work characteristics, family norms, and the use of WCBA to manage boundaries between work and home are complex. Further, although faculty have a great deal of flexibility in choosing when to work and 
even to some extent their work location, it is argued here that each faculty member may have his/her own implicit definition of what constitutes work and non-work time and respond to afterhours connectivity to the workplace accordingly.

\section{Strengths, Limitations, and Future Research}

A strength of our research is that it is field research examining employees at a variety of job types within an organization. It is important that future research draw upon a broad array of types of organizations that provide a range of workplace rules, demands, and norms. Future research should also continue to examine workers in a variety of jobs, consistent with DiRenzo, Greenhaus, and Weer's (2011) observations that the relationship between work and family demands and WFC may be affected by job type. Given the proliferation of new communication technologies which provide both increased opportunities and expectations for connection across the boundaries between work and family, it is important that we better understand how WCBA may be associated with WFC. This is especially important in light of the fact that these communication technologies are facilitating a trend toward flex-time and flex-place work policies. We must also consider that boundaries between home and work are differentially permeable and that worker preferences for integration versus segmentation are not static. Future studies should consider individual boundary management profiles (e.g. Kossek et al., 2012). Longitudinal research may be employed to assess the dynamic nature of these preferences. Further, as Valcour and Hunter (2005) noted, the mere availability of technology may drive perceptions that after-hours connectivity is desirable. Future research should examine such perceptions.

We used Richardson and Benbunan-Fich's (2011) measure of WCBA which assessed the duration of WCBA at various times of the day. This measure does require participants to estimate their levels of WCBA. In future studies it may be fruitful for participants to be prompted to record actual WCBA when prompted by an alarm similar to the study design used by Williams and Alliger (1994) to examine work-family spillover. A limitation of the study is the fact that all variables were measured using self-reports. The fact that some variables, such as job type and whether the employer provided communication technology, are objective in nature lessens the concerns of using self-reported data to some extent. Survey responses were anonymous, and as Conway and Lance (2010) noted, anonymity may reduce response bias.

\section{Implications for Practice}

The findings suggest that employees who desire a greater degree of role integration will be more likely to use communication devices to connect with the workplace after hours. Not surprisingly, workplace requirements to be connected after hours also led to WCBA. The finding that WCBA was not associated with WFC when job type and hours worked after hours were controlled suggests that hours worked rather than how the work occurred is more strongly related to WFC. Thus, employees and their managers should be conscious of the employee using communication devices to connect with the workplace after hours only when it is necessary for the operation of the organization (for example, emergency personnel) or when it enables employees who prefer higher levels of role integration to achieve such integration. For example, parents of school-age children may prefer to be able to leave the workplace early to pick their child up from school in the afternoon, and resume working from home later in the evening. 
Employees and their managers should both be conscious of how communication devices are used and guard against using them to simply extend work hours. Managers may consider actively creating workplace norms promoting work life balance. Employees may consciously guard their time and allow their work after-hours to match their role integration preferences. The findings also suggest that family members may influence employees' choices to control interruptions from communication devices rather than the absolute use of such devices. Again, such behavioral control may allow employees who prefer a higher degree of role integration to meet family needs as well as the demands of the workplace. This finding emphasizes the importance of communicating explicitly with family members regarding actively managing work life balance.

\section{Conclusion}

This study showed that requirements for after-hours connections and role integration preference were associated with the use of technology for after-hours connectivity to the workplace. Apparently, workers use communication technology to meet employer demands for after-hours communication as well as to satisfy their own preference for work-life integration. The relationship between WCBA and WFC was not significant when job level and hours worked after hours were controlled suggesting that while the availability of communication technology plays a role in managing the boundaries between work and home, job type and total hours worked may be more important. Fit between the job type and preferences for role integration is likely to have an effect on whether the employee experiences WFC or other forms of distress from WCBA. Clearly, the network of relationships between work and home variables is complex.

\section{References}

Adkins, C. L. \& Premeaux, S. F. (2012). Spending Time: The Impact of Hours Worked on Work-Family Conflict. Journal of Vocational Behavior, 80, 380-389. doi: 10.1016/j.jvb.2011.09.003

Ashforth, B. E., Kreiner, G. E., \& Fugate, M. (2000). All in a day's work: Boundaries and micro role transitions. Academy of Management Review, 25, 472-491. doi: 10.5465/AMR.2000.3363315

Batt, R. \& Valcour P.M. (2003). Human resources practices as predictors of work-family outcomes and employee turnover. Industrial Relations, 42, 189-220. doi: 10.1111/1468232X.00287

Boswell, W. R., \& Olson-Buchanan, J. B. (2007). The use of communication technologies after hours: The role of work attitudes and work-life conflict. Journal of Management, 33, 592-610. doi: 10.1177/0149206307302552

Boyar, S. L., Maertz, C. P., Mosley, D. C., \& Carr, J. C. (2008). The impact of work/family demand on work/family conflict. Journal of Managerial Psychology, 23, 215-235. doi: $10.1108 / 02683940810861356$

Burke, M. E. (2004). Generational Differences Survey Report. Alexandria, VA: Society for Human Resource Management. 
Chesley, N. N. (2005). Blurring boundaries? Linking technology use, spillover, individual distress, and family satisfaction. Journal of Marriage and Family, 67, 1237-1248. doi:10.1111/j.1741-3737.2005.00213

Clark, S. C. (2000). Work-family border theory: A new theory of work-family balance. Human Relations, 53, 747-770. doi: 10.1177/0018726700536001

Clark, S. C. (2002). Communicating across the work/home border. Community, Work, \& Family. 5, 23-48. doi: 10.1080/13668800020006802

Conway, J. M. \& Lance, C. E. (2010). What reviewers should expect from authors regarding common method bias in organizational research. Journal of Business and Psychology, 25, 325-344. doi: 10.1007.s10869-010-9181-6

Desrochers, S. \& Sargent, L. D. (2004). Boundary/border theory and work-family integration. Organization Management Journal, 1, 40-48.

DiRenzo, M. S., Greenhaus, J. H., \& Weer, C. H. (2011). Job level, demands, and resources as antecedents of work-family conflict. Journal of Vocational Behavior, 78, 305-314. doi: 10.1016/j.jvb.2010.10.002

Eby, L. T., Casper, W. J., Lockwood, A., Bordeaux, C., \& Brinley, A. (2005). Work and family research in IO/OB: Content analysis and review of the literature (1980-2002). Journal of Vocational Behavior, 66, 124-197. doi: 10.1016/j.jvb.2003.11.003

Edwards, J. \& Rothbard, N, (1999). Work and family stress and well-being: An examination of person-environment fit in the work and family domains. Organizational Behavior and Human Decision Processes, 77, 85-129. doi: 10.1006/obhd.1998.2813

Fenner, G. H. \& Renn, R. W. (2004). Technology-assisted supplemental work: Construct definition and a research framework. Human Resource Management, 43, 179-200. 10.1002/hrm.20014

Fishbein, M., \& Ajzen, I. (1975). Belief, attitude, intention, and behavior: An introduction to theory and research. Reading, MA: Addison-Wesley Pub. Co.

Galinsky, E., Kim, S. S., \& Bond, J. T. (2001). Feeling overworked: When work becomes too much. New York: Families and Work Institute.

Golden, T. D. (2011). Altering the effects of work and family conflict on exhaustion: Telework during traditional and nontraditional work hours. Journal of Business and Psychology, Published online 06 November 2011. doi: 10.1007/s10869-011-9247-0

Golden, A., \& Geisler, C. (2007). Work-life boundary management and the personal digital assistant. Human Relations, 60, 519-551. doi: 10.1177/0018726707076698

Greenhaus, J. H., \& Beutell, N. J. (1985). Sources of conflict between work and family roles.

Academy of Management Review, 10, 76-88. doi: 10.5465/AMR.1985.4277352

Grönlund, A. (2007). More control, less conflict? Job demand-control, gender and work-family conflict. Gender, Work and Organization, 14, 476-497. doi: 10.1111/j.14680432.2007.00361.x

Heponiemi, T., Elovainio, M., Pekkarinen, L., Sinervo, T., \& Kouvonen A. (2008). The effects of job demands and low job control on work-family conflict: The role of fairness in decision making and management. Journal of Community Psychology, 36, 387-398. doi: 10.1002/jcop. 20200

Hughes, E. L. \& Parkes, K. R. (2007). Work hours and well-being: The roles of work-time control and work-family interference. Work \& Stress, 21, 264-278. doi: $10.1080 / 02678370701667242$ 
Kelly, E. L. \& Moen, P. (2007). Rethinking the clockwork of work: Why schedule control may pay off at work and at home. Advances in Developing Human Resources, 9, 487-506. doi: $10.1177 / 1523422307305489$

Kossek, E. E., Lautsch, B. A., \& Eaton, S. C. (2006). Telecommuting, control, and boundary management: Correlates of policy use and practice, job control, and work-family effectiveness. Journal of Vocational Behavior, 68, 347-367. doi: 10.1016/j.jvb.2005.07.002

Kossek, E. E., Ruderman, M. N., Braddy, P. W., \& Hannum, K. M. (2012). Work-nonwork boundary management profiles: A person-centered approach. Journal of Vocational Behavior, 81, 112-128. doi: 10.1016/j.jvb.2012.04.003

Kreiner, G. E. (2006). Consequences of work-home segmentation or integration: a personenvironment fit perspective. Journal of Organizational Behavior, 27, 485-507. doi: 10.1002/job.386

Kreiner, G. E., Hollensbe, E.C. \& Sheep, M. L. (2009). Balancing borders and bridges: Negotiating the work-home interface via boundary work tactics. Academy of Management Journal, 52, 704-730. doi: 10.5465/AMJ.2009.43669916

Netemeyer, R. G., Boles, J. S., \& McMurrian, R. (1996). Development and validation of workfamily and family-work conflict scales. Journal of Applied Psychology, 81, 400-410. doi: 10.1037//0021-9010.81.4.400

Olson-Buchanan, J. B., \& Boswell, W. R. (2006). Blurring boundaries: Correlates of integration and segmentation between work and nonwork. Journal of Vocational Behavior, 68, 432445. doi: 10.1016/j.jvb.2005.10.006

Powell, G. N., \& Greenhaus, J. H. (2010). Sex, gender, and the work-to-family interface: Exploring negative and positive interdependencies. Academy of Management Journal, 53, 513-534. doi: 10.5465/AMJ.2010.51468647

Richardson, K. M. \& Benbunan-Fich, R. (2011). Examining the antecedents of work connectivity behavior during non-work time. Information and Organization, 21, 142-160. doi:10.1016/j.infoandorg.2011.06.002

Richardson, K. M., \& Rothstein, H. R. (2008), "Examining the situational and individual correlates of workplace connectivity behavior", paper presented at Academy of Management Annual Meeting, Anaheim, CA. doi:10.5465/AMBPP.2008.33641774

Rothbard, N. P., Phillips, K. W., \& Dumas, T. L. (2005). Managing multiple roles: Work-family policies and individuals' desires for segmentation. Organization Science, 16, 243-258. doi: 10.1287 /orsc. 1050.0124

Rothberg, D. (2006, June 9). BlackBerry on the beach: You call this a real vacation? EWeek. Available from http://www.eweek.com/c/a/IT-Management/BlackBerry-on-the-BeachYou-Call-This-a-Vacation, (accessed 19 February, 2009).

Schlosser, F. K. (2002). So, how do people really use their handheld devices? An interactive study of wireless technology use. Journal of Organizational Behavior, 23, 401-423. doi: 10.1002/job.146

Sonnentag, S. (2003). Recovery, work engagement, and proactive behavior: A new look at the interface between nonwork and work. Journal of Applied Psychology, 88, 518-528. Doi: 10.1037/0021-9010.88.3.518

Towers, I., Duxbury, L., Higgins, C., \& Thomas, J. (2006). Time thieves and space invaders: Technology, work and the organization. Journal of Organizational Change Management, 19, 593-618. doi: 10.1108/09534810610686076 
Turner, J. W., Grube, J.A., Tinsley, C. H., Lee, C., \& O'Pell, C. (2006). Exploring the dominant media: How does media use reflect organizational norms and affect performance? The Journal of Business Communication, 43, 220-250. doi: 10.1177/0021943606288772

Valcour, P. M. \& Hunter, L. (2005). Technology, organizations, and work-life integration. In Kossek, E. \& Lambert, S. (Eds.) Work and Life Integration: Organizational, Cultural, and Individual Perspectives (pp. 61-84). Mahwah, NJ: Lawrence Erlbaum.

Venkatesh, V. \& Davis, F. (2000). A theoretical extension of the technology acceptance model: Four longitudinal field studies. Management Science, 46, 186-204. doi: 10.1287/mnsc.46.2.186.11926

Wajcman, J., Bittman, M., \& Brown, J. (2008). Families without borders: Mobile phones, connectedness and work-home divisions. Sociology, 42, 635-652. doi:10.1177/0038038508091620

Williams, K., \& Alliger, G.M . (1994). Role stressors, mood spillovers, and perceptions of workfamily conflict in employed parents. Academy of Management Journal, 37, 837-868. doi: $10.2307 / 256602$ 